Jurnal Biologi dan Pembelajarannya, Vol 6 No 2, Oktober 2019. Pp: 1-3

e-ISSN: $2406-8659$

\title{
Pengaruh Media Pembelajaran Critical Wheel Berbasis Problem Based Learning (PBL) pada Materi Animalia Terhadap Kemampuan Berpikir Kritis Siswa Kelas X SMA/MA
}

\author{
Auliya Durrotun Nasikhah, Eva Nurul Malahayati, Devita Sulistiana \\ Universitas Islam Balitar \\ e-mail: auliya1909@gmail.com
}

\begin{abstract}
Abstrak
Tujuan dari penelitian ini adalah mengetahui pengaruh media pembelajaran Critical Wheel terhadap kemampuan berpikir kritis siswa mata pelajaran biologi materi animalia. Desain penelitian yang diterapkan adalah pretest-posttest control group design dengan instrumen berupa test essay. Berdasarkan perhitungan dengan SPSS pada uji ANCOVA diketahui pengaruh penggunaan media Critical Wheel pada kelas eksperimen adalah sebesar $9,6 \%$.
\end{abstract}

Kata kunci-Critical Whee, Problem Based Learning, Berpikir Kritis

\section{PENDAHULUAN}

Berdasarkan UU RI Nomor 20 Tahun 2003 pendidikan memiliki fungsi untuk mengembangkan kemampuan, membentuk watak dan peradaban dari suatu bangsa, sehingga guru memiliki peran sebagai penentu keberhasilan tujuan pendidikan dan proses pembelajaran di sekolah. Suatu bangsa dapat dinilai berhasil dan maju apabila mutu pendidikan di dalamnya juga mendukung, hal tersebut dapat terjadi karena pendidikan merupakan hal terpenting dalam kehidupan. Pengembangan pengetahuan dan intelektual, serta pembentukan watak dan sikap ke arah yang positif dapat diperoleh melalui pendidikan yang layak. Sifat dinamis yang ada pada pendidikan menjadikannya selalu berubah mengikuti perkembangan zaman sebagai perbaikan pembelajaran atau praktik pendidikan.

Salah satu hal yang dibutuhkan dalam praktik pendidikan dan mendukung tercapainya tujuan pembelajaran yaitu penggunaan media pembelajaran. Melalui media pembelajaran hal-hal yang kompleks dapat disederhanakan [1]. Pernyataan tersebut memberikan pemahaman bahwa penyampaian pesan atau materi pembelajaran yang padat dapat disampaikan secara singkat dan jelas dengan penggunaan media. Oleh karena itu, media pembelajaran sangat dibutuhkan keberadaannya, guna mendukung dalam peningkatkan kualitas pengajaran. Tanpa media pembelajaran, guru akan membutuhkan tenaga dan waktu yang lebih dalam penyampaiannya dibanding dengan menggunakan media dan siswa juga akan lebih mudah dalam menerima pesan yang disampaikan. Namun fakta yang diperoleh dari hasil observasi lapang, guru kurang bahkan jarang menggunakan media pembelajaran yang bervariasi. Sebesar $77,8 \%$ guru melakukan pembelajaran dengan metode ceramah atau presentasi di depan kelas.

Pada penelitian ini, media pembelajaran yang digunakan adalah media cetak berupa Critical Wheel, yakni sebuah media yang telah dikembangkan dari permainan meja roulette, media pembelajaran tersebut akan membuat siswa berpikir, berbicara, mendengarkan dan saling bekerja sama [2]. Selain menggunakan media sebagai pendukung tercapainya tujuan belajar, hal yang dapat menunjang pembelajaran agar efektif dan efesien adalah penerapan strategi pembelajaran yang tepat [3]. Problem based learning merupakan model pembelajaran yang diterapkan pada media tersebut sebagai strategi untuk membawa peserta didik kewilayahnya sendiri dengan sebuah wadah belajar dikehidupan nyata.

Sebagai tujuan dari penelitian ini adalah adanya pengaruh dari media tersebut terhadap kemampuan berpikir kritis, yang mana berpikir kritis merupakan proses berpikir pada taraf lebih tinggi dan termasuk kemampuan yang penting untuk dimiliki dan dilatihkan pada siswa sebagai pemecahan berbagai masalah yang dihadapi dalam kehidupan dengan menganalisis kembali, mengidentifikasi, mengevaluasi, mempertimbangkan, dan mengembangkan kembali semua ide dan asumsi hingga memunculkan satu keputusan atau kesimpulan [4]. Hal tersebut diharapkan telah sesuai dengan konsep literasi sains yang menuntut mampu untuk memahami, untuk selanjutnya mengkomunikasikan, serta mengaplikasikan dalam kehidupan nyata.

\section{METODE PENELITIAN}

Sebagai subjek penelitian kami adalah siswa-siswi kelas X MIA 8 dan kelas X MIA 9 SMA Negeri 1 Talun Blitar, dengan teknik pengambilan sampel tersebut adalah Purposive Sampling yang merupakan jenis dari nonprobability sampling, yakni teknik penentuan sampel berdasarkan dari pertimbangan kelas yang memiliki rata- 
Jurnal Biologi dan Pembelajarannya, Vol 6 No 2, Oktober 2019. Pp: 1-3

e-ISSN: $2406-8659$

rata hasil belajar dan karakteristik siswa yang hampir sama, jumlah siswa yang sama, dan kelas yang digunakan tersebut tidak dapat diacak-acak oleh peneliti.

Desain penelitian kami adalah pretest-posttest control group design yang melibatkan dua kelompok subjek (kelompok kontrol dan kelompok eksperimen) dengan kategori penelitiannya adalah Quasi Eksperimental. Quasi Eksperimental merupakan penelitian yang bertujuan mengungkapkan hubungan sebab akibat [5].

\begin{tabular}{lccc}
\hline \multicolumn{1}{c}{ Grup } & Pretest & Perlakuan & Posttest \\
\hline Eksperimen & $\mathrm{Y} 1$ & $\mathrm{X} 1$ & $\mathrm{Y} 2$ \\
\hline Control & $\mathrm{Y} 1$ & - & $\mathrm{Y} 2$ \\
\hline
\end{tabular}

Keterangan.

X1 : perlakuan (pembelajaran) menggunakan media pembelajaran Critical Wheel pada kelas eksperimen

Y1 : pretest kelompok eksperimen sebelum menggunakan media pembelajaran Critical Wheel

Y1 : pretest kelompok kontrol

Y2 : posttest kelompok eksperimen sesudah menggunakan media pembelajaran Critical Wheel

Y2 : posttest kelompok kontrol

Data skor kemampuan berpikir kritis dianalisis dengan ketentuan pedoman penskoran sehingga diperoleh skor mentah. Pedoman penskoran kemampuan berpikir kritis yang peneliti gunakan mengacu pada penskoran yang dikembangkan oleh Ennis [5]. Instrumen pada penelitian ini berupa tes essay dengan jenjang C4-C6 sesuai ranah kognitif pada taksonomi Bloom.

\section{HASIL DAN PEMBAHASAN}

Media yang digunakan adalah Critical Wheel, yakni media pembelajaran yang dikembangkan dari permainan roda putar atau roulate dengan menggunakan model pembelajaran PBL sebagai penunjang untuk meningkatkan kemampuan berpikir kritis siswa. Media Critical Wheel, diujicobakan dengan tujuan untuk mengetahui pengaruh penggunaan media tersebut terhadap kemampuan berpikir kritis siswa kelas $\mathrm{X}$.

\section{Descriptive Statistics}

Dependent Variable:berpikir_kritis

\begin{tabular}{lrrr}
\hline critical_wheel & Mean & Std. Deviation & \multicolumn{1}{c}{ N } \\
\hline menggunakan_media & 22.60 & 2.078 & 30 \\
tidak_menggunakan_media & 13.50 & 2.886 & 30 \\
Total & 18.05 & 5.222 & 60 \\
\hline
\end{tabular}

Berdasarkan perolehan rata-rata hasil posttest untuk kemampuan berpikir kritis pada kelas eksperimen adalah 22,60, sedangkan rata-rata pada kelas kontrol adalah 13,50 dengan pengaruh perbedaan perlakuan ditunjukkan oleh Partial Eta Squared sebesar 0,688 atau 68,8\%.

Berdasarkan hasil uji ANCOVA, media pembelajaran Critical Wheel dapat berpengaruh secara signifikan terhadap kemampuan berpikir kritis siswa karena pada media yang dikembangkan memiliki fokus pemecahan masalah yang nyata. Berdasarkan stimulus atau permasalahan nyata yang diberikan, siswa akan tertantang dalam mengembangkan pengetahuannya. Menurut Ennis [5], berpikir kritis adalah berpikir yang memiliki landasan atau beralasan dan reflektif dengan menekankan pada pembuatan keputusan mengenai hal apa yang harus dipercayai atau dilakukan. Siswa dapat melakukan analisis proses, mengamati segala hal guna menjawab permasalahan dengan ide yang dikembangkan serta berlandaskan dengan teori yang akurat.

Pada praktiknya, media Critical Wheel diawali dengan penyajian suatu masalah untuk selanjutnya didiskusikan dalam sebuah kelompok, siswa mendefinisikan masalah dan mengidentifikasi apa yang siswa butuhkan serta hal-hal yang belum diketahui. Selanjutnya siswa melakukan pengkajian pustaka dari materi yang termuat dalam media untuk mencari tahu kebenaran dan menyelesaikan masalah di luar bimbingan guru dengan mengkaji materi yang terdapat pada media. Sehingga dengan proses pembelajaran tersebut diharapkan siswa akan terdorong untuk dapat aktif dalam pengembangannya terhadap taraf berpikir kritis. Hal tersebut juga diperkuat dengan hasil penelitian yang telah dilakukan oleh Wulansari (2017) [6], yang 
Jurnal Biologi dan Pembelajarannya, Vol 6 No 2, Oktober 2019. Pp: 1-3

e-ISSN: $2406-8659$

mengembangkan media roda pintar dengan hasil $72 \%$ dari siswa menyukai pembelajaran dengan media tersebut.

\section{Tests of Between-Subjects Effects}

Dependent Variable:kritis

\begin{tabular}{|c|c|c|c|c|c|c|}
\hline Source & $\begin{array}{c}\text { Type III Sum of } \\
\text { Squares }\end{array}$ & Df & Mean Square & $\mathrm{F}$ & Sig. & $\begin{array}{l}\text { Partial Eta } \\
\text { Squared }\end{array}$ \\
\hline $\begin{array}{l}\text { Corrected } \\
\text { Model }\end{array}$ & $2010.384^{\mathrm{a}}$ & 2 & 1005.192 & 73.518 & .000 & .721 \\
\hline Intercept & 425.603 & 1 & 425.603 & 31.128 & .000 & .353 \\
\hline Pretest & 15.118 & 1 & 15.118 & 2.106 & .000 & .096 \\
\hline critical_wheel & 1644.250 & 1 & 1644.250 & 120.257 & .000 & .688 \\
\hline Error & 779.349 & 57 & 13.673 & & & \\
\hline Total & 54182.000 & 60 & & & & \\
\hline $\begin{array}{l}\text { Corrected } \\
\text { Total }\end{array}$ & 2789.733 & 59 & & & & \\
\hline
\end{tabular}

a. $\mathrm{R}$ Squared $=.721$ (Adjusted R Squared $=.711)$

Pengaruh kemampuan berpikir kritis pada penelitian ini adalah sebesar 9,6\% karena terdapat beberapa faktor yang mempengaruhi diantaranya waktu pembelajaran yang hanya sebatas enam jam pelajaran dengan pembahasan materi yang cukup padat, sehingga siswa kurang memiliki waktu meneliti untuk memecahkan masalah yang diberikan. Serta media yang memiliki cakupan kurang luas pada aspek materi sehingga dirasa kurang mendukung pada pemecahan masalah yang ada. Namun, dapat disimpulkan bahwa penggunaan media pembelajaran Critical Wheel memliki efektifitas terkait pengaruh kemampuan berpikir kritis siswa kelas X pada materi animalia.

\section{SIMPULAN}

Pengaruh penggunaan media pembelajaran Critical Wheel memliki efektifitas terkait kemampuan berpikir kritis siswa kelas X pada materi animalia sebesar 7,1\%.

\section{SARAN}

\section{UCAPAN TERIMA KASIH}

\section{DAFTAR PUSTAKA}

1) Sudjana. 2005. Metode Statistika. Bandung : Tarsito.

2) Salmawati. 2012. Penerapan Model Pembelajaran Roda Keberuntungan untuk Meningkatkan Hasil Belajar Matematika Kelas IV SDN 011 Pancuran Gading Kecamatan Tapung Kabupaten Kampar. Skripsi, Pendidikan Guru Madrasah Ibtidaiyah, Fakultas Tarbiyah dan Keguruan, Universitas Islam Negeri Sultan Syarif Kasim Riau.

3) Roestiah NK. 2001. Strategi Belajar Mengajar. Jakarta : Rineka Cipta.

4) Suparmi. 2015. Bahan Ajar Berbasis Problem Based Learning untuk Meningkatkan Kemampuan Berfikir Kritis Siswa. Skripsi, Universitas Negeri Semarang.

5) Ennis RH. 2011. The Nature of Critical Thinking : An Outline of Critical Thinking Dispositions and Abilities. University of Illinois.

6) Yuli W \& Durinta P. Pengembangan Media Pembelajaran Permainan Roda Pintar pada Mata Pelajaran Administrasi Kepegawaian Kelas XI. Skripsi, Pendidikan Administrasi Perkantoran, Fakultas Ekonomi, Universitas Negeri Surabaya. 